\title{
Original article (Orijinal araştırma) \\ Effects of artificial diets and floral nectar on parasitization performance of Trichogramma brassicae Bezdenko, 1968 (Hymenoptera: Trichogrammatidae) ${ }^{1}$
}

\author{
Yapay besin ve bitki nektarının Trichogramma brassicae Bezdenko, 1968
} (Hymenoptera: Trichogrammatidae)'nin parazitleme performansına etkileri

\author{
Nihal ÖZDER ${ }^{2^{*}}$
}

\author{
Şeyda DEMIRTAŞ ${ }^{2}$
}

\section{Summary}

This study was conducted to determine whether various food resources enhanced the longevity and fecundity of the egg parasitoid Trichogramma brassicae Bezdenko, 1968 (Hymenoptera: Trichogrammatidae) under laboratory conditions $\left(25^{\circ} \mathrm{C}, 65 \% \mathrm{RH}, 16 \mathrm{~L}: 8 \mathrm{D} \mathrm{h}\right.$ photoperiod) at Laboratory of Biological Control, Department of Plant Protection, Agriculture Faculty, Namık Kemal University in 2014. Newly hatched female wasps were fed on Ephestia kuehniella Zeller, 1879 (Lepidoptera: Pyralidae) eggs with either honey, grape molasses and royal jelly as a main food, alone or double combination of this main foods or supplemented with resin (derived from plants), acacia nectar, Paulownia nectar, red tulip nectar, yellow asphodel nectar, apple syrup, liquid of $E$. kuehniella eggs or mashed E. kuehniella larvae. Trichogramma brassicae, females that were fed on honey and acacia nectar (17.47 d), honey + apple syrup (17.20 d), honey (16.93 d) and honey + Paulownia nectar $(16.60 \mathrm{~d})$ lived significantly longer than females that fed on other floral nectars and artificial diets. Females were fed on royal jelly + mashed E. kuehniella larvae $(1.40 \mathrm{~d})$ had the shortest longevity. Trichogramma brassicae females that were fed on honey (106.8 eggs), honey + acacia nectar (105.4 eggs), Paulownia nectar (103.13 eggs) parasitized significantly more hosts than females that fed on other floral nectars and artificial diets. Females fed on royal jelly were had the lowest parasitizing ability (3.33 eggs). These results showed that providing T. brassicae with honey, honey + acacia nectar, honey + apple syrup resulted in greater longevity and total fecundity than other food resources.

Keywords: Trichogramma brassicae, Ephestia kuehniella, floral nectar, food, fecundity, longevity

\section{Özet}

$\mathrm{Bu}$ çalışma, çeşitli besin kaynaklarının yumurta parazitoiti Trichogramma brassicae Bezdenko, 1968 (Hymenoptera: Trichogrammatidae)'e etkilerinin araştırılması amacıyla Namık Kemal Üniversitesi, Ziraat Fakültesi, Bitki Koruma Bölümü, Biyolojik Mücadele Laboratuvarı'nda laboratuvar koşullarında $\left(25^{\circ} \mathrm{C}\right.$ sıcaklık, \%65 nem, 16:8 saat (aydınlık: karanlık) aydınlanma periyodu) 2014 yılında yürütülmüştür. Ergin dişi bireyler, değirmen güvesi Ephestia kuehniella Zeller, 1879 (Lepidoptera: Pyralidae) yumurtaları üzerinde ana besin (bal, üzüm pekmezi ve arı sütü) ve ara besin (reçine (bitkilerden salgılanan), akasya nektarı, çin kavağı nektarı, kırmızı lale nektarı, sarızambak nektarı, elma şurubu, E. kuehniella yumurta sıvısı ve ezilmiş E. kuehniella larvası) ve bu ana besinlerin ikili kombinasyonları ile beslenmiştir. Bal + akasya nektarı (17.47 gün), bal + elma şurubu (17.20 gün), bal + çin kavağı nektarı (16.60 gün) ile beslenen bireylerin diğer besin ve nektar ile beslenen bireylere göre daha uzun yaşadığı belirlenmiştir. En kısa ömür ise arı sütü + ezilmiş $E$. kuehniella larvası (1.40 gün) ile beslenen bireylerde görülmüştür. Çalışma sonucunda toplam parazitlenen yumurta sayısı, bal (106.8 yumurta), bal + akasya nektarı (105.4 yumurta), çin kavağı nektarı (103.13 yumurta) ile beslenen bireylerde ve belirgin olarak diğer besin ile beslenen bireylerin parazitledikleri yumurta sayılarından fazla bulunmuştur. Arı sütü ile beslenen bireylerin parazitledikleri yumurta sayısı (3.33 yumurta) en düşük olarak belirlenmiştir. Bu sonuçlar, T. brassicae'ye bal, bal + akasya nektarı, bal + elma şurubu verilmesinin diğer gıda kaynaklarına göre daha uzun ömür ve toplam doğurganlık sağladığını göstermiştir.

Anahtar sözcükler: Trichogramma evanescens, Ephestia kuehniella, bitki nektarı, besin, yumurta verimi, ömür

\footnotetext{
${ }^{1}$ This work is a part of Master Science thesis and this study was undertaken as a part of research Project supported by the Namık Kemal University research fund NKUBAP. 00.24.AR.13.11.

${ }^{2}$ Department of Plant Protection, Faculty of Agriculture, Namık Kemal University, 59030, Tekirdağ, Turkey

* Corresponding author (Sorumlu yazar) e-mail: nozder@nku.edu.tr

Received (Alınış): 07.10.2016 Accepted (Kabul ediliş): 14.12.2016 Published Online (Çevrimiçi Yayın Tarihi): 15.03.2017
} 


\section{Introduction}

Egg parasitoids are most important parasitoids for biological control programs. Trichogramma species are the most widely used biological control agent. Trichogramma wasps are used against lepidopterans in biological control programs around the world (Li, 1994; Smith, 1996).

Food has a significant effect on parasitoid performance, such as developmental time, survival, fecundity and longevity (Hohmann et al., 1988; Fuchsberg et al., 2007; Özder \& Kara, 2010, Tunçbilek et al., 2012). Parasitization performance of Trichogramma spp. (longevity, fecundity, adult emergence and female emergence) is known to be influenced by extrafloral nectar, pollen, honey, carbohydrate and protein (Ashley \& Gonzalez, 1974; Hohmann et al., 1988; Baggen et al., 1999; Jervis et al., 2004; Lee et al., 2004, Shearer \& Atanassov, 2004; Zhang et al., 2004; Wäckers, 2005; Witting-Bissinger, 2008).

Field release requires a large number of Trichogramma individuals (Stinner et al.,1974; Jalali \& Singh, 1992). Many studies have focused on the mass rearing and storage of Trichogramma species (Jalali \& Singh, 1992; Özpınar \& Kornoşor, 1993; Özpınar, 1994; Karabörklü \& Ayvaz, 2007; Yılmaz et al., 2007; Ayvaz et al., 2008).

Study on the mass rearing of parasitoids has focused primarily on food. Both longevity and fecundity of parasitoids can increase with of certain kinds of food (Ashley \& Gonzalez, 1974; Özkan, 2007; Tunçbilek et al., 2012; Çınar et al., 2015) In the field parasitoids can obtain carbohydrates in homopteran honeydew, floral and extrafloral nectar (Wäckers et al., 2008). A number of studies have provided considerable evidence for increased parasitoid abundance and parasitism level when flowering plants are present (Berndt et al., 2006; Diaz et al., 2012, Masetti et al., 2010; Zhu et al., 2013).

Acacia nectar, Paulownia nectar, red tulip nectar, yellow asphodel nectar, honey, grape molasses and royal jelly were chosen for this study because of their floral morphology and they are widely planted in in gardens. Also, several laboratory studies have shown that hymenopteran parasitoids exhibit increased longevity and fecundity when provided with honey.

The aim of this study was to determine the effects of food sources on Trichogramma brassicae Bezdenko, 1968 (Hymenoptera: Trichogrammatidae) longevity, parasitism rate, progeny production and progeny sex ratio for mass rearing and in the field.

\section{Materials and Methods}

Trichogramma brassicae used in this experiment had been continuously reared on eggs of the Mediterranean flour moth, Ephestia kuehniella Zeller, 1879 (Lepidoptera: Pyralidae) since 1998 in the laboratory at $25 \pm 1{ }^{\circ} \mathrm{C}$ and $70 \pm 5 \% \mathrm{RH}$ with a $16 \mathrm{~L}: 8 \mathrm{D} \mathrm{h}$ photoperiod. Fresh (less than $24 \mathrm{~h}$ old) $\mathrm{E}$. kuehniella eggs were glued on pieces of white cardboard $(2 \times 4 \mathrm{~cm})$ and were then placed in glass vials $(7.5 \times 2 \mathrm{~cm})$. These eggs were offered to single $T$. brassicae females for $24 \mathrm{~h}$ and then were discarded. Females used in the experiments were newly emerged, mated and lacked egg laying experience. Sex ratio was calculated by using the form of the antenna to distinguish the adult females (Özder, 2006).

Eggs of E. kuehniella were used for rearing and as host eggs in the experiment. Ephestia kuehniella were reared on wheat bran. Throughout the rearing, cultures were kept in a rearing room, equipped with a control system, at $25 \pm 1^{\circ} \mathrm{C}, 70 \pm 5 \% \mathrm{RH}$. To obtained eggs, approximately 100 mated females of Mediterranean flour moth were collected from stock cultures and released in plastic jars (Özder \& Kara, 2010). 
Twenty-seven diet treatments were assessed (Table 1). Mature females were fed with either honey, grape molasses or royal jelly as a main food, alone or supplemented with resin (derived from plants), acacia nectar, Paulownia nectar, red tulip nectar, yellow asphodel nectar, apple syrup, liquid of $E$. kuehniella egg and mashed E. kuehniella larvae. All of the female parasitoids were fed daily until all female parasitoids died.

About 50 fresh $E$. kuehniella eggs were placed in glass vials $(10 \times 3 \mathrm{~cm})$ and newly emerged $(<24 \mathrm{~h})$ T. brassicae females were introduced and held for $24 \mathrm{~h}$. After exposure, the adults were removed and the number of parasitized eggs counted. Fresh eggs of $E$. kuehniella were exposed to $T$. brassicae adults in glass vials until all female parasitoids died. All experiments were carried out at $25 \pm 1^{\circ} \mathrm{C}$ and $70 \pm 5 \% \mathrm{RH}$ with a 16L:8D $\mathrm{h}$ photoperiod. Treatments were replicated 15 times. The number of parasitized eggs, adults and sex ratio were determined after the larval and pupal development of the parasitoids. For each sample sheet, the number of host eggs parasitized (blackened eggs) was counted daily for $5 \mathrm{~d}$ following exposure. To assess the effect of the diets on the longevity of $T$. brassicae, the flowers and other diets were offered simultaneously to single $T$. brassicae females. Treatments were replicated 15 times and the food sources and cardboard sheets were replaced daily until all parasitoids died. The longevity of each female was recorded. The flowers were brought to the laboratory and cleaned of any plant parts and insects that may have fallen into the collection cylinder. Different whole flower with nectar were offered to $T$. brassicae females in glass tubes (vials). Honey, molasses and the other diets were dotted onto the paper with a sharpened dissecting probe to provide four dots no larger than $2 \mathrm{~mm}$ in diameter. Flowers were collected daily and spread on white paper under a lamp to check for insects and then offered to the parasitoids.

Data were analyzed using SPSS 8 Windows. A one-way analysis of variance (ANOVA) was used to study the effects of the food sources applied as a factor and the number of parasitized eggs, adult emergence and female emergence as parasitization efficiency dependent. Means were compared Duncan's Multiple Range test was applied as a means of separation.

\section{Results}

\section{Longevity}

The longevity of $T$. brassicae females was influenced by their diet (Table 1). When royal jelly $+E$. kuehniella larvae were given, $T$. brassicae individuals lived for only $1.40 \pm 0.50 \mathrm{~d}$. Honey + acacia nectar significantly increased the longevity of females $(P<0.05)$ of $T$. brassicae. Females lived the longest when fed with honey + acacia nectar $(17.46 \pm 6.52 \mathrm{~d})$, honey + apple syrup $(17.20 \pm 4.44 \mathrm{~d})$, honey $(16.93 \pm 3.91 \mathrm{~d})$ and honey + Paulownia nectar (16.60 $\pm 4.54 \mathrm{~d})$.

\section{Fecundity}

Diet had a significant effect on fecundity $(P<0.05)$. The percentage of fecundity was significantly greater on honey (106.8 \pm 30.26 eggs), honey + acacia nectar (105.4 \pm 12.26 eggs) and honey + Paulownia nectar (103.13 \pm 15.34 eggs), than royal jelly + red tulip nectar (3.33 \pm 1.34$)$ eggs) (Table 1). A large variation was found within the diets as regards fecundity. The mean parasitism decreased dramatically, especially for females on fed royal jelly and royal jelly + resin.

\section{Adult emergence}

The parasitoid completed development on all diets tested (Table 1). The greatest adult emergence was obtained on royal jelly + red tulip nectar (100\%) and royal jelly + E. kuehniella larvae $(100 \%)$.

\section{Female emergence}

The numbers of females that emerged were significantly affected by the food given. The numbers of female progeny which emerged were different from the pattern shown in the number of parasitized eggs. The highest female emergence was obtained royal jell and combinations (Table 1). 
Effects of artificial diets and floral nectar on parasitization performance of Trichogramma brassicae Bezdenko, 1968 (Hymenoptera: Trichogrammatidae)

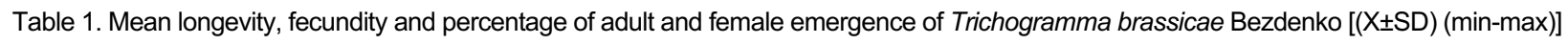

\begin{tabular}{|c|c|c|c|c|}
\hline Diets & Longevity $(\mathrm{d})^{*}$ & Fecundity* & Adult emergence $(\%)^{\star}$ & Female emergence $(\%)^{\star}$ \\
\hline Honey & $\begin{array}{c}16.93 \pm 3.91 \\
(9-23) \mathrm{H}\end{array}$ & $\begin{array}{c}106.8 \pm 30.26 \\
(55-149) \mathrm{L}\end{array}$ & $\begin{array}{c}98.86 \pm 2.35 \\
(91-100) B C D\end{array}$ & $\begin{array}{c}85.00 \pm 3.81 \\
(78-95) C D\end{array}$ \\
\hline Molasses & $\begin{array}{c}11.60 \pm 5.17 \\
(4-22) G\end{array}$ & $\begin{array}{c}91.60 \pm 24.03 \\
(55-131) \mathrm{KL}\end{array}$ & $\begin{array}{c}97.93 \pm 2.76 \\
(92-100) A B C\end{array}$ & $\begin{array}{c}85.13 \pm 2.87 \\
(80-90) C D\end{array}$ \\
\hline Royal jelly & $\begin{array}{c}3.00 \pm 0.92 \\
(2-5) C D\end{array}$ & $\begin{array}{l}7.40 \pm 4.5 \\
(2-15) A B\end{array}$ & $\begin{array}{c}97.20 \pm 5.63 \\
(80-100) A B C D\end{array}$ & $\begin{array}{c}89.53 \pm 10.84 \\
(73-100) F\end{array}$ \\
\hline Honey + acacia nectar & $\begin{array}{c}17.46 \pm 6.52 \\
(7-26) \mathrm{H}\end{array}$ & $\begin{array}{c}105.40 \pm 12.26 \\
(78-121) L\end{array}$ & $\begin{array}{c}99.33 \pm 1.04 \\
(97-100) \text { BCD }\end{array}$ & $\begin{array}{c}85.46 \pm 1.92 \\
(83-89) \mathrm{CD}\end{array}$ \\
\hline Honey + Paulownia nectar & $\begin{array}{c}16.60 \pm 4.54 \\
(8-23) \mathrm{H}\end{array}$ & $\begin{array}{c}103.13 \pm 15.34 \\
(79-126) L\end{array}$ & $\begin{array}{c}99.26 \pm 1.16 \\
(97-100) \text { BCD }\end{array}$ & $\begin{array}{c}83.60 \pm 3.56 \\
(75-89) C\end{array}$ \\
\hline Honey + apple syrup & $\begin{array}{c}17.20 \pm 4.44 \\
(10-24) \mathrm{H}\end{array}$ & $\begin{array}{c}80.20 \pm 19.84 \\
(36-110) \mathrm{JK}\end{array}$ & $\begin{array}{c}98.33 \pm 1.49 \\
(95-100) A B C\end{array}$ & $\begin{array}{c}83.00 \pm 3.22 \\
(78-90) C\end{array}$ \\
\hline Honey + yellow asphodel nectar & $\begin{array}{c}7.66 \pm 3.69 \\
(4-17) F\end{array}$ & $\begin{array}{c}67.93 \pm 40.70 \\
(28-151) \mathrm{HI}\end{array}$ & $\begin{array}{c}98.13 \pm 1.80 \\
(95-100) A B C\end{array}$ & $\begin{array}{c}79.13 \pm 5.48 \\
(71-86) B C\end{array}$ \\
\hline Honey + red tulip nectar & $\begin{array}{c}14.60 \pm 3.83 \\
(8-19) \mathrm{H}\end{array}$ & $\begin{array}{c}74.80 \pm 29.11 \\
(33-125) \text { iJ }\end{array}$ & $\begin{array}{c}99.06 \pm 1.43 \\
(96-100) \text { BCD }\end{array}$ & $\begin{array}{c}80.53 \pm 2.87 \\
(75-86) C\end{array}$ \\
\hline Honey + E. kuehniella larvae & $\begin{array}{c}6.66 \pm 2.49 \\
(4-11) \mathrm{EF}\end{array}$ & $\begin{array}{c}51.93 \pm 23.01 \\
(23-97) \mathrm{G}\end{array}$ & $\begin{array}{c}98.06 \pm 1.98 \\
(94-100) A B C\end{array}$ & $\begin{array}{c}79.20 \pm 6.57 \\
(65-87) B C\end{array}$ \\
\hline Honey + E. kuehniella eggs & $\begin{array}{l}9.66 \pm 2.55 \\
(5-14) G\end{array}$ & $\begin{array}{c}74.40 \pm 19.87 \\
(32-97) \mathrm{IJ}\end{array}$ & $\begin{array}{c}98.93 \pm 1.53 \\
(96-100) \text { BCD }\end{array}$ & $\begin{array}{c}84.93 \pm 4.78 \\
(72-89) \mathrm{CD}\end{array}$ \\
\hline Honey + resin & $\begin{array}{c}10.13 \pm 2.13 \\
(6-13) G\end{array}$ & $\begin{array}{c}57.66 \pm 13.60 \\
(39-89) \mathrm{GH}\end{array}$ & $\begin{array}{c}98.06 \pm 1.83 \\
(96-100) A B C\end{array}$ & $\begin{array}{c}81.93 \pm 2.40 \\
(78-85) C\end{array}$ \\
\hline Molasses + yellow asphodel nectar & $\begin{array}{l}7.00 \pm 1.30 \\
(5-10) \mathrm{EF}\end{array}$ & $\begin{array}{c}32.20 \pm 10.59 \\
(16-59) \mathrm{F}\end{array}$ & $\begin{array}{c}98.53 \pm 3.06 \\
(89-100) \text { BCD }\end{array}$ & $\begin{array}{c}69.20 \pm 3.66 \\
(63-75) A\end{array}$ \\
\hline Molasses + red tulip nectar & $\begin{array}{l}5.73 \pm 1.90 \\
\quad(2-9) E\end{array}$ & $\begin{array}{c}29.73 \pm 16.28 \\
(12-66) \mathrm{F}\end{array}$ & $\begin{array}{c}98.40 \pm 3.92 \\
(86-100) B C D\end{array}$ & $\begin{array}{c}70.26 \pm 4.78 \\
(57-77) A B\end{array}$ \\
\hline Molasses + apple syrup & $\begin{array}{c}10.13 \pm 2.66 \\
(5-13) G\end{array}$ & $\begin{array}{c}65.73 \pm 19.07 \\
(37-100) \mathrm{IJ}\end{array}$ & $\begin{array}{l}99.53 \pm 1.24 \\
(96-100) C D\end{array}$ & $\begin{array}{c}80.73 \pm 3.41 \\
(75-86) C\end{array}$ \\
\hline Molasses + Paulownia nectar & $\begin{array}{c}9.93 \pm 2.18 \\
(6-13) G\end{array}$ & $\begin{array}{c}56.60 \pm 13.38 \\
(38-89) \mathrm{GH}\end{array}$ & $\begin{array}{l}99.20 \pm 1.69 \\
(95-100) C D\end{array}$ & $\begin{array}{l}78.86 \pm 3.92 \\
(71-84) \text { BC }\end{array}$ \\
\hline Molasses + Acacia Nectar & $\begin{array}{c}5.60 \pm 2.16 \\
(3-10) E\end{array}$ & $\begin{array}{c}36.26 \pm 18.22 \\
\quad(7-77) \mathrm{F}\end{array}$ & $\begin{array}{c}98.26 \pm 2.08 \\
(94-100) A B C D\end{array}$ & $\begin{array}{l}78.26 \pm 7.78 \\
(67-100) B C\end{array}$ \\
\hline Molasses + E. kuehniella larvae & $\begin{array}{c}3.06 \pm 1.16 \\
(2-5) C D\end{array}$ & $\begin{array}{c}16.86 \pm 8.45 \\
(7-37) \mathrm{DC}\end{array}$ & $\begin{array}{l}96.06 \pm 4.21 \\
(87-100) A B\end{array}$ & $\begin{array}{c}83.00 \pm 6.64 \\
(73-100) C\end{array}$ \\
\hline Molasses + E. kuehniella eggs & $\begin{array}{l}5.60 \pm 2.09 \\
(2-9) E\end{array}$ & $\begin{array}{c}23.80 \pm 7.39 \\
(9-33) \mathrm{EF}\end{array}$ & $\begin{array}{c}97.00 \pm 4.14 \\
(86-100) A B C\end{array}$ & $\begin{array}{l}77.73 \pm 5.50 \\
(67-83) A B C\end{array}$ \\
\hline Molasses + resin & $\begin{array}{l}3.53 \pm 1.18 \\
(2-6) C D\end{array}$ & $\begin{array}{c}12.80 \pm 5.01 \\
(5-23) \mathrm{BC}\end{array}$ & $\begin{array}{c}94.73 \pm 5.92 \\
(85-100) A\end{array}$ & $\begin{array}{c}83.60 \pm 10.28 \\
(70-100) C D\end{array}$ \\
\hline Royal jelly + Paulownia nectar & $\begin{array}{c}3.06 \pm 0.70 \\
(2-4) C D\end{array}$ & $\begin{array}{c}13.13 \pm 6.94 \\
(6-34) \mathrm{BC}\end{array}$ & $\begin{array}{c}97.00 \pm 5.25 \\
(87-100) A B C D\end{array}$ & $\begin{array}{c}80.40 \pm 7.56 \\
(67-100) C\end{array}$ \\
\hline Royal jelly + red tulip nectar & $\begin{array}{c}2.40 \pm 0.50 \\
(2-3) B C\end{array}$ & $\begin{array}{c}3.33 \pm 1.34 \\
(2-7) A\end{array}$ & $\begin{array}{l}100.0 \pm 0.00 \\
(100-100) D\end{array}$ & $\begin{array}{c}97.73 \pm 6.08 \\
(80-100) G\end{array}$ \\
\hline
\end{tabular}


Table 1. (Continued)

\begin{tabular}{lcccc}
\hline \multicolumn{1}{c}{ Diets } & Longevity $(\mathrm{d})^{*}$ & Fecundity* $^{*}$ & Adult emergence $(\%)^{*}$ Female emergence $(\%)^{*}$ \\
\hline Royal jelly + acacia nectar & $3.66 \pm 0.72$ & $20.00 \pm 8.16$ & $98.00 \pm 2.64$ & $94.20 \pm 4.17$ \\
& $(2-5) \mathrm{D}$ & $(11-46) \mathrm{DE}$ & $(93-100) \mathrm{ABCD}$ & $(88-100) \mathrm{EF}$ \\
& $2.93 \pm 0.70$ & $9.53 \pm 4.30$ & $97.80 \pm 4.84$ & $96.46 \pm 4.58$ \\
Royal jelly + resin & $(2-4) \mathrm{CD}$ & $(3-18) \mathrm{B}$ & $(86-100) \mathrm{BCD}$ & $(88-100) \mathrm{G}$ \\
& $3.06 \pm 0.88$ & $9.06 \pm 4.80$ & $97.73 \pm 4.11$ & $97.20 \pm 4.87$ \\
Royal jelly + apple syrup & $(2-5) \mathrm{CD}$ & $(3-21) \mathrm{B}$ & $(88-100) \mathrm{ABCD}$ & $(87-100) \mathrm{G}$ \\
& $1.40 \pm 0.50$ & $8.86 \pm 3.75$ & $100.0 \pm 0.00$ & $97.60 \pm 4.18$ \\
Royal jelly + E. kuehniella larvae & $(1-2) \mathrm{A}$ & $(5-18) \mathrm{B}$ & $(100-100) \mathrm{D}$ & $(89-100) \mathrm{G}$ \\
& $1.86 \pm 0.74$ & $9.26 \pm 3.51$ & $96.46 \pm 4.59$ & $89.60 \pm 9.25$ \\
Royal jelly + E. kuehniella eggs & $(1-3) \mathrm{AB}$ & $(4-16) \mathrm{B}$ & $(88-100) \mathrm{ABC}$ & $(71-100) \mathrm{F}$ \\
& $1.93 \pm 1.03$ & $11.13 \pm 6.17$ & $96.46 \pm 4.77$ & $83.26 \pm 12.15$ \\
Royal jelly + yellow asphodel nectar & $(1-4) \mathrm{AB}$ & $(3-21) \mathrm{BC}$ & $(88-100) \mathrm{ABC}$ & $(50-100) \mathrm{CD}$ \\
\hline
\end{tabular}

* Mean in a column the same letters are not significantly different $(P<0.05)$

\section{Discussion}

All natural floral nectars and artificial diets allowed $T$. brassicae to complete development. This indicates that there is a potential for rearing this parasitoid on artificial and floral nectars. Fecundity of $T$. brassicae females was greater honey, honey + acacia nectar and honey + Paulownia poplar nectar and this value were significantly higher from those obtained on others. The number of parasitization was lowest royal jelly + red tulip nectar. Cruden \& Hermann (1983) found that cut flowers may produce less nectar that intact flowers. Our results correspond with the finding of (Witting-Bissinger, 2008) where Trichogramma exiguum Pinto \& Platner, 1978 longevity and fecundity were increased significantly when wasps were provided honey and honey + buckwheat. Our results are supported by other studies which found and increase in longevity and fecundity with honey or flowers as a food sources compared with water or no food (Özkan, 2007; Tunçbilek et al., 2012; Çınar et al., 2015).

In this study, with honey as a food source, mean female longevity was ten times longer, and the mean fecundity was 100 times greater than with royal jelly. A number of studies have shown that an increase in fecundity can occur when parasitoid wasps are provided particular food (Leius, 1961; Ashley \& Gonzalez, 1974; Yu et al., 1984; Leatemia et al., 1995; Aydin Özder \& Kılınçer, 1996 a, b; Blanche et al., 1996; Gurr \& Nicol, 2000; Johanowicz \& Mitchell, 2000; Costamagna \& Landis, 2004; Shearrer \& Atanassov, 2004; Fuchsberg et al., 2007; Özkan, 2007; Tunçbilek et al., 2012; Lessard \& Boivin, 2013; Çınar et al., 2015). Saljoqi \& Khattak (2007) reported that adult Trichogramma chilonis Ishii, 1941 females provided with $50 \%$ honey and water lived significantly longer than unfed females or those provided with some other kind of food. Feeding has been shown to increase the longevity of Trichogramma platneri Nagarkatti, 1975 (Hohmann et al., 1989). Although the availability of honey markedly affected the longevity of $T$. platneri, it did not increase fecundity (Hohmann et al., 1989). Özder et al. (2011) reported that Trichogramma evanescens Westwood, 1833 longevity increased significantly when wasps were provided corn pollen + honey compared to pollen alone. In other studies, the mean fecundity of mated females fed with was similar to unfed females (Hohmann et al., 1989, Özder, 2006; Özder \& Kara, 2010).

Nectar is a good food for insects, and nectar and pollen have positive effects on longevity, fecundity, adult emergence and female emergence (Lewis \& Takasu, 1990; Wäckers, 1994; Patt et al., 1999; Thompson \& Hagen, 1999; Wäckers, 2003). Zhang et al. (2004) showed that $T$. brassicae females fed on corn pollen plus water had significantly increased longevity and fecundity compared with those fed on water alone. Also, Zhu et al. (2015) reported that T. chilonis females provided Sesamum indicum L. flowers lived significantly longer and had significantly increased fecundity than when on provided water. 
Trichogrammatid egg parasitoids have been used to reduce egg hatching and subsequent damage caused by larval pests. The success of biological control program may largely depend on potential reproductive rate (the number of adult female progeny produced by a female parasitoid in the presence unlimited prey). In our study, a higher ratio of female to male offspring was observed in $T$. brassicae females provided royal jelly and royal jelly combination. This was probably due to the special food. Royal jelly is a honey bee secretion that is used in nutrition of larvae as well as adult queens and includes water, protein, fat, enzyme, hormone, vitamin and some micronutrients. When worker bees make a new queen, they choose small larvae and feed them with royal jelly. This type of feeding triggers the development of queen morphology including the fully developed ovaries needed to lay eggs (Doğaroğlu \& Doğaroğlu, 2015).

Food quality is important in determining the effectiveness of parasitoids as control agents. We conclude that artificial and natural diets are effective for rearing $T$. brassicae, based on parasitization, adult emergence and female longevity. In the current study, artificial diets proved to be suitable foods for sustaining the development and reproduction of $T$. brassicae. Floral nectar qualities may be of importance to parasitoid longevity when selecting floral resources for conservation biological control. Nectar sugar composition may also be crucial in determining its nutritional suitability.

Our results suggest that honey, grape molasses, acacia nectar and Paulownia nectar food sources could serve as food sources for $T$. brassicae in stores, warehouses and in the field. While information on the effect of food resources on longevity and reproduction output of parasitoids are important to the study of biological control, additional studies on royal jelly and feeding behavior of parasitoids in the field are needed.

\section{Acknowledgments}

This work was supported by the Namık Kemal University Research Fund under grant number NKUBAP. 00.24.AR.13.11.

\section{References}

Ashley, T. R. \& D. Gonzalez, 1974. Effect of various food substances on longevity and fecundity of Trichogramma. Environmental Entomology, 3 (1): 169-171.

Aydın Özder, N. \& N. Kılınçer, 1996a. Investigations on some biological relations between Agrotis segetum (Denis and Schiff) (Lepidoptera: Noctuidae) and Trichogramma embryophagum (Hartig) and T. turkeiensis Kostadinov (Hymenoptera; Trichogrammatidae). Türkiye Entomoloji Dergisi, 20 (1): 35-49.

Aydın Özder, N. \& N. Kılınçer, 1996b. The effect of Agrotis segetum (Denis and Schiff) (Lepidoptera: Noctuidae) eggs age and pattern, food and temperature on longevity, fecundity, progeny and parasitism rate of Trichogramma embryophagum (Hartig) and $T$. turkeiensis Kostadinov (Hymenoptera: Trichogrammatidae). Türkiye Entomoloji Dergisi, 20 (2): 83-92.

Ayvaz, A., E. Karasu, S. Karabörklü \& A. Ş. Tunçbilek, 2008. Effect of cold storage, rearing temperature, parasitoid age and irradiation on the performance of Trichogramma evanescens Westwood (Hymenoptera: Trichogrammatidae). Journal of Stored Products Research, 44 (3): 232-240.

Baggen, G. M. \& A. M. Gurr, 1999 Flowers in tri-tropic system: mechanism allowing selective exploitation by insect natural enemies for conservation biological control. Entomologia Experimentalis et Applicata, 91: 155-161.

Berndt, L. A., S. D. Wratten \& S. L. Scarratt, 2006. The influence of floral resource subsides on parasitism rates of leafrollers (Lepidoptera: Tortricidae) in New Zealand vineyards. Biological Control, 37 (1): 50-55.

Blanche, S., J. Cassas, F. Bigler \& K. E. Jansen-van Bergeijk, 1996. An individual-based model of Trichogramma foraging behaviour: Parameter estimation for single females. Journal of Applied Ecology, 33: 425-434.

Costamagna, A. C. \& D. A. Landis, 2004. Effects of food resources on adult Glyptapanteles militaris and Meteorus. Environmental Entomology, 3 (1): 169-171.

Cruden, R. W. \& S. M. Herman, 1983. "Studying Nectar? Some Observations on the Art, 223-241". In: The Biology of Nectaries, (Eds. B. Bentley \& T. Ellias). Columbia University Press, New York, 259 pp. 
Çınar, N., S. Bakır \& A. S. Tunçbilek, 2015. Comparative effects of flower nectar and artificial diets on some biological aspects of the parasitoid species Bracon hebetor (Say.) Hymenoptera: Braconidae). Egyptian Journal of Biological Pest Control, 25 (1): 233-236.

Diaz, M. F., A. Ramírez \& K. Poveda, 2012. Efficiency of different egg parasitoids and increased floral diversity for the biological control of noctuid pests. Biological Control, 60 (2): 182-191.

Doğaroğlu, M. \& O. K. Doğaroğlu, 2015. Modern Arıcılık Teknikleri. Anadolu Matbaa, İstanbul, $320 \mathrm{~s}$.

Fuchsberg, J. F., T. Z. Yong, J. E. Losey, M. E. Carter, \& M. P. Hoffmann, 2007. Evaluation of corn leaf aphid (Rhopalosiphum maidis; Homoptera: Aphididae) honeydew as a food source for the egg parasitoid Trichogramma ostriniae (Hymenoptera: Trichogrammatidae). Biological Control, 40 (2): 230-236.

Gurr, G. M. \& H. I. Nicol, 2000. Effect of food on longevity of adults of Trichogramma carverae Oatman and Pinto and Trichogramma brassicae Bezdenko (Hymenoptera: Trichogrammatidae). Australian Journal of Entomology, 39: 185-187.

Hohmann, C. L., R. F. Luck \& E. R. Oatman, 1988. A comparison of longevity and fecundity of adult Trichogramma platneri (Hymenoptera: Trichogrammatidae) reared from eggs of the cabbage looper and the angoumois grain moth, with and without access to honey. Journal of Economic Entomology, 81: 1307-1312.

Hohmann, C. L., R. F. Luck, E. R. Oatman \& G. R. Platner, 1989. Effects of different biological factors on longevity and fecundity of Trichogramma platneri Nagarkatti (Hymenoptera: Trichogrammatidae). Anais da Sociedade Entomologica do Brasil, 18: 61-70.

Jalali, S. K. \& S. P. Singh, 1992. Differential response of four Trichogramma species to low temperatures for short term storage. Entomophaga, 37: 159-165.

Jervis, M. A., J. C. Lee \& G. E. Heimpel, 2004. "Use of Behavioral Life-History Studies to Understand the Effect of Habitat Manipulation, 65-100". In: Ecological Engineering for Pest Management, (Eds. G. M. Gurr, M. A. Wratten \& M. A. Altieri), Comstok Publishing Associates, Ithaca, NY 232 pp.

Johanowicz, D. L. \& E. R. Mitchell, 2000. Effects of sweet alyssum flowers on the longevity of the parasitoid wasps Cotesia marginiventris (Hymenoptera: Braconidae) and Diadegma insulare (Hymenoptera: Ichneumonidae). Florida Entomologist, 83: 41-47.

Karabörklü, S. \& A. Ayvaz, 2007. Soğukta depolamanın farklı konukçularda yetişen Trichogramma evanescens Westwood (Hym: Trichogrammatidae)'in farklı evreleri üzerine etkileri. Erciyes Üniversitesi Fen Bilimleri Enstitüsü Dergisi, 23: 30-36.

Leatemia, J. A., J. E. Laing \& J. E. Corrigan, 1995. Effects of adult nutrition on longevity, fecundity, and offspring sex ratio of Trichogramma minutum Riley (Hymenoptera: Trichogrammatidae). Canadian Entomologist, 127 (2): 245-254.

Lee, J. C., G. E. Heimpel \& G. L. Leibee, 2004. Comparing floral nectar and aphid honeydew diets on the longevity and nutrient levels of a parasitoid wasp. Entomologia Experimentalis et Applicata, 111: 189-199.

Leius, K., 1961. Influence of food on fecundity and longevity of adults of Itoplectis conquisitor (Say) (Hymenoptera: Ichneumonidae). Canadian Entomologist, 93: 771-780.

Lessard, E. \& G. Boivin, 2013. Effect of age and hunger on host-feeding behavior by female Trichogramma euproctidis (Hymenoptera: Trichogrammatidae). Canadian Entomologist, 145 (1): 53-60.

Lewis, W. J. \& K. Takasu, 1990. Use of learned odors by a parasitic wasp in accordance with host and food needs. Nature, 348: 635-636.

Li, L. Y, 1994. "Worldwide use of Trichogramma for Biological Control of Different Crops: A Survey, 37-54". In: Biological Control with Egg Parasitoids, (Eds. E. Wajnberg \& S. A. Hassan). CAB International, Wallingford, 286 pp.

Masetti, A., Lanzoni \& G. Burgio, 2010. Effects of flowering plants on parasitism of lettuce leafminers (Diptera: Agromyzidae). Biological Control, 54 (3): 263-269.

Özder, N., 2006. Comparative biology and life tables of Trichogramma brassicae and Trichogramma cacoeciae with Ephestia kuehniella as host at three constant temperatures. The Great Lakes Entomolgist, 39(1\&2): 62-66.

Özder, N. \& G. Kara, 2010. Comparative biology and life tables of Trichogramma cacoeciae, T. brassicae and T. evanescens e (Hymenoptera: Trichogrammatidae) with Ephestia kuehniella and Cadra cautella (Lepidoptera, Pyralidae) as hosts at three constant temperatures. Biocontrol Science and Technology, 20 (3): 245-255.

Özder, N., Ö, Sağlam, B. Korkmaz, G. Demir \& Ş. Demirtaş, 2011. "Yumurta parazitoidleri Trichogramma brassicae Bezdenko ve Trichogramma evanescens Westwood (Hymenoptera: Trichogrammatidae) türlerine bitki poleninin etkileri, 223". Türkiye IV. Bitki Koruma Kongresi Bildirileri (28-30 Haziran 2011, Kahramanmaraş), 317 s. 
Effects of artificial diets and floral nectar on parasitization performance of Trichogramma brassicae Bezdenko, 1968 (Hymenoptera: Trichogrammatidae)

Özkan, C., 2007. Effect of food, light and and host instar on the egg load of the synovigenic endoparasitoid Venturia canescens (Hymenoptera: Ichneumonidae). Journal of Pest Science, 80: 79-83.

Özpinar, A. \& S. Kornoşor, 1993. Ephestia küehniella Zeller (Lepidoptera, Pyralidae) yumurtaları üzerinde Trichogramma evanescens West. (Hym., Trichogrammatidae)'in bazı biyolojik özelliklerinin araştırılması. Çukurova Üniversitesi Ziraat Fakültesi Dergisi, 8: 131-142.

Özpinar, A., 1994.Trichogramma evanescens Westwood (Hym., Trichogrammatidae)'in iki farklı konukçudaki yaşam çizelgesi. Türkiye Entomoloji Dergisi, 18 (2): 83-88.

Patt, J. M., G. C. Hamilton \& J. H. Lashomb, 1999. Responses of two parasitoid wasps to nectar odors as a function of experience. Entomologia Experimentalis et Applicata, 90: 1-8.

Saljoqi, A. U. R. \& A. S. K. Khattak, 2007. Effect of different artificial diets on the efficiency and development of Trichogramma chilonis (Ishii) (Hymenoptera: Trichogrammatidae). Sarhad Journal of Agriculture, 23: 129-133.

Shearer, P. W. \& A. Atanassov, 2004. Impact of peach extra floral nectar on key biological characteristics of Trichogramma minutum (Hymenoptera: Trichogrammatidae). Journal of Economic Entomology, 97: 789-792.

Smith, S. M., 1996. Biological control with Trichogramma: advances, successes, and potential of their use. Annual Review of Entomology, 41: 375-406.

Stinner, R. E., R. L. Ridgway \& R. E. Kinzer, 1974. Storage, manipulation of emergence, and estimation of number of Trichogramma pretiosum. Environmental Entomology, 3: 504-507.

Thompson, S. N. \& K. S. Hagen, 1999. "Nutrition of Entomophagous Insects and Other Arthropods, 594-652". In: Handbook of Biological Control, (Eds. T. S. Bellows, T. W. Fisher, L. E. Caltagirone, D. L. Dahlsten, C. Huffaker \& G. Gardh), Academic, San Diego, CA. 1031 pp.

Tunçbilek A. Ş., N. Çınar \& Ü. Canpolat, 2012. Bitki nektarı ve yapay besinlerin Trichogramma euproctidis Girault (Hymenoptera: Trichogrammatidae)'in ömür uzunluğu ve döl verimi üzerine etkisi. Türkiye Entomoloji Dergisi, 36 (2): 183-191.

Wäckers, F. L., 1994. The effect of food deprivation on the innate visual and olfactory preferences in the parasitoid Cotesia rubecula. Journal of Insect Physiology, 40: 641-649.

Wäckers, F. L., 2003. "The parasitoids' Need for Sweets: Sugars in Mass Rearing and Biological Control, 59-72". In: Quality Control and Production of Biological Control Agents, Theory and Testing Procedure (Ed. J. C. van Lenteren) CABI Publishing, Cambridge, $327 \mathrm{pp}$.

Wäckers, F. L., 2005. "Suitability of (Extra-) Floral Nectar, Pollen, and Honeydew as Insect Food Sources, 14-74". Plant-Provided Food for Carnivorous Insect: A Protective Mutualism and its Applications, (Eds. F. L. Wäckers, P. C. J. van Rijn \& J. Bruin) Cambridge University Press, Cambridge, 356 pp.

Wäckers, F. L., P. C. J. van Rijin \& G. E. Heimpel, 2008. Honeydew as a food source for natural enemies: Making the best of a bad meal. Biological Control, 45 (2): 176-184.

Witting-Bissinger, B. E., D. B. Orr \& H. M. Linker, 2008. Effect of floral resources on fitness of the parasitoids Trichogramma exiguumm (Hymenoptera: Trichogrammatidae) and Cotesia congregata (Hymenoptera: Braconidae). Biological Control, 47 (2): 180-186.

Yılmaz, S., S. Karabörklü \& A. Ayvaz, 2007. Effect of cold temperature durations on the performance of the adult Trichogramma evanescens (Westwood, 1833) Hymenoptera: Trichogrammatidae). Türkiye Entomoloji Dergisi 31 (4): 269-278.

Yu, D. S. K., E. A. C. Hagley \& J. E. Laing, 1984. Biology of Trichogramma minutum Riley collected from apples in southern Ontario. Environmental Entomology, 13: 1324-1329.

Zhang, G. R., O. Zimmermann, \& S. A. Hassan, 2004. Pollen as a source of food for egg parasitoids of the genus Trichogramma (Hymenoptera: Trichogrammatidae). Biocontrol Science and Technology, 14: 201-209.

Zhu, P. Y., G. M. Gurr, Z. X. Lu, K. L. Heong, G. H. Chen, X. S. Zheng, H. X. Xu \& Y. J. Yang, 2013. Laboratory screening supports the selection of sesame (Sesamum inducum) to enhance Anagrus spp. Parasitoids (Hymenoptera: Mymaridae) of rice planthoppers. Biological Control, 64 (1): 83-89.

Zhu, P., G. Wang, Z. Xusong, T. Junce, Z. Lu, K. L. Heong, H. Xu, G. Chen, Y. Yang \& G. M. Gur, 2015. Selective enhancement of parasitoids of rice Lepidoptera pests by sesame (Sesamum indicum) flowers. BioControl, 60: $157-167$ 